\title{
WHO Collaborating Centre for Acquired Immunodeficiency Syndrome for the Eastern Mediterranean Regional Office, Faculty of Medicine, Kuwait University, Kuwait
}

\author{
Haya Altawalah Widad Al-Nakib \\ WHO Collaborating Centre for AIDS, Health Sciences Centre, Faculty of Medicine, Kuwait University, \\ Kuwait City, Kuwait
}

\section{Key Words}

WHO collaboration centre $\cdot$ HIV workshop $\cdot$ Annual symposia

\begin{abstract}
In the early 1980s, the World Health Organization (WHO) designated the Virology Unit of the Faculty of Medicine, Health Sciences Centre, Kuwait University, Kuwait, a collaborating centre for AIDS for the Eastern Mediterranean Regional Office (EMRO), recognizing it to be in compliance with WHO guidelines. In this centre, research integral to the efforts of WHO to combat AIDS is conducted. In addition to annual workshops and symposia, the centre is constantly updating and renewing its facilities and capabilities in keeping with current and latest advances in virology. As an example of the activities of the centre, the HIV-1 RNA viral load in plasma samples of HIV-1 patients is determined by realtime PCR using the AmpliPrep TaqMan HIV-1 test v2.0. HIV-1 drug resistance is determined by sequencing the reverse transcriptase and protease regions on the HIV-1 pol gene, using the TRUGENE HIV-1 Genotyping Assay on the OpenGene ${ }^{\circledR}$ DNA Sequencing System. HIV-1 subtypes are determined by sequencing the reverse transcriptase and protease regions on the HIV-1 pol gene using the genotyping assays
\end{abstract}

described above. A fundamental program of Kuwait's WHO AIDS collaboration centre is the national project on the surveillance of drug resistance in human deficiency virus in Kuwait, which illustrates how the centre and its activities in Kuwait can serve the EMRO region of WHO.

(c) 2014 S. Karger AG, Basel

\section{Introduction}

The World Health Organization's (WHO) collaborating centre by definition is 'an institution designated by the director-general to form part of an international collaborative network carrying out activities in support of the organization's programme at all levels' [1]. These centres represent WHO's vision and mission in implementing its mandated work [1].

- Vision: WHO collaborating centres are key institutions with relevant expertise distributed throughout the world. They represent a valuable resource as an extended and integral arm of WHO's capacity to implement its mandated work.

- Mission: WHO collaborating centres are a highly valued mechanism of cooperation in which selected institutions are recognized by WHO to assist the organiza-

\begin{tabular}{ll}
\hline KARGER & $\begin{array}{l}\text { @ 2014 S. Karger AG, Basel } \\
1011-7571 / 14 / 0237-0047 \$ 39.50 / 0 \quad \text { Karger }\end{array}$ \\
E-Mail karger@karger.com & $\begin{array}{l}\text { This is an Open Access article licensed under the terms of the } \\
\text { Creative Commons Attribution-NonCommercial 3.0 Un- } \\
\text { ported license (CC BY-NC) (www.karger.com/OA-license), } \\
\text { applicable to the online version of the article only. Distribu- } \\
\text { tion permitted for non-commercial purposes only. }\end{array}$
\end{tabular}

Dr. Haya Altawalah

Virology Unit, Department of Microbiology

Health Sciences Centre, Faculty of Medicine, Kuwait University

Kuwait (Kuwait)

E-Mail dr.altawalah@gmail.com 
tion with implementing its mandated work. This is accomplished by supporting the achievement of planned strategic objectives at regional and global levels, enhancing the scientific validity of its global health work and developing and strengthening institutional capacity in countries and regions.

The concept of a collaborating centre is to provide a service, be it certain investigations or training in a specific field. The collaborative centres should have ample expertise available for consultation and/or training. These centres strategically serve WHO, both locally and regionally. The centre at the Faculty of Medicine, Health Sciences Centre, Kuwait University, is one of the WHO collaborative centres fulfilling this role.

\section{Description of the Centre}

In the early 1980s, the Faculty of Medicine's centre was designated a WHO collaboration centre [2] as it fulfilled all the required criteria of WHO [1-3], including the following:

- High scientific and technical standing at national and international levels

- Prominent place in the country's health, scientific or educational structures

- High quality of scientific and technical leadership and sufficient number of staff with high-level qualifications

- Stability in terms of personnel, activity and funding

- Strong working relationship with other institutions in the country and at inter-country, regional and global levels

- Clear ability, capacity and readiness to contribute, both individually and within networks, to WHO programme activities, whether in support of country programmes or through participation in international cooperative activities

- Clear technical and geographical relevance of both the institution and its activities to WHO's programme priorities

- At least 2 years of previous collaboration with WHO in carrying out jointly planned activities

Kuwait's centre is re-designated a WHO collaboration centre every 4 years following evaluation and approval by the relevant WHO responsible officer and technical staff [1-3]. The current director is Professor Widad Al-Nakib. The centre has approximately 34 staff members, including 3 consultants, $3 \mathrm{PhD}$ specialist staff members, an average of 6-8 medical residents at any one time, a labora- tory manager, and approximately 20 technicians. It also has access to many established specialists, including immunologists and molecular biologists.

The centre's main activities include providing consultation in virology and acting as a reference centre for HIV and other virological investigations for the Eastern Mediterranean Regional Office (EMRO), holding annual symposia on recent advances in clinical virology and annual training workshops on HIV. In addition, the centre has devised a service to detect HIV drug resistance and provide HIV genotyping [1-3]. These activities, included in the terms of reference as agreed upon with WHO in the current 4-year designation plan [2], are as follows:

- Hold annual symposia on recent advances in clinical virology in collaboration with EMRO every year from 2009 to 2012; all the symposia will cover aspects of recent advances in the study of HIV/AIDS

- Hold annual training workshops on the application of molecular techniques in the diagnosis and management of HIV/AIDS in the Eastern Mediterranean Region in collaboration with EMRO every year from 2009 to 2012

- Conduct virological consultations for the Eastern Mediterranean region

- Perform reference work for HIV drug resistance, sequencing, confirmation and genotyping

In 2012, over 153,564 virological investigations were conducted by the centre. The range of investigations is wide and includes investigations of FluA, CMV, HSV, $\mathrm{EBV}$, adenovirus, parvovirus, polyoma virus, varicellazoster virus, $\mathrm{HHV}-6, \mathrm{HCV}$, enteroviruses, respiratory viruses, HIV, and HBV using sophisticated molecular methods. The throughput of samples and patients through the centre in general virology has reached some 25,000 patient referrals per annum from local hospitals and medical centres.

\section{HIV Work}

In compliance with its terms of reference with WHO, the centre is continuously renewing and updating its equipment and techniques to meet the highest international specifications. A national project funded by Kuwait University for surveillance of drug resistance in HIV infection in Kuwait was awarded a grant of KWD 125,000 on April 1, 2011. Sophisticated equipment was purchased under this grant, for example, the TRUGENE sequencer [4], for genotyping HIV and identifying drug resistance to antiretroviral drugs.
Altawalah/Al-Nakib 
In 2010, the centre acquired two sophisticated devices, the AmpliPrep TaqMan [5] (advanced technology in the field of HIV viral load estimation) and the ABI sequencer [6] (very advanced technology for viral genome sequencing).

In the centre, HIV-1 RNA viral load in plasma samples of HIV-1 patients is determined by real-time PCR using the AmpliPrep TaqMan HIV-1 test v2.0 (Roche Diagnostic Systems, Branchburg, N.J., USA). The test can detect HIV-1 RNA over the range of 20-10,000,000 copies $/ \mathrm{ml}$. One copy of HIV-1 RNA is equivalent to $1.7 \pm 0.1 \mathrm{IU}$, based on the WHO first international standard for HIV-1 RNA for nucleic acid-based techniques. The results are expressed as copies/ml.

HIV-1 drug resistance is determined by sequencing the reverse transcriptase and protease regions on the HIV-1 pol gene, using the TRUGENE HIV-1 Genotyping Assay on the OpenGene ${ }^{\circledR}$ DNA Sequencing System (Siemens Healthcare Diagnostics, Deerfield, Ill., USA). This is the only test cleared by the FDA for use with viral loads of 1,000 copies $/ \mathrm{ml}$. When equivocal results are obtained with the TRUGENE assay, ViroSeq ${ }^{\mathrm{TM}}$ HIV-1 Genotyping System (Abbott Laboratories, Abbott Park, Ill., USA) on the ABI Prism ${ }^{\circledR} 3130 x$ Genetic Analyzer (Applied Biosystems, Foster City, Calif., USA) is used. This assay is FDA approved and can detect HIV-1 viral resistance in plasma samples with a viral load ranging from 2,000 to 750,000 copies $/ \mathrm{ml}$. Phylogenetic analysis is performed to detect cross-contamination between samples.

HIV-1 subtypes are determined by sequencing the reverse transcriptase and protease regions on the HIV-1 pol gene using the genotyping assays described above. The obtained sequences are then analysed and compared to sequences available from the GenBank database.

\section{The Relationship between HIV Investigations and Dentistry}

Dentists play a significant role in predicting the response to treatment with highly active antiretroviral therapy (HAART) and the emergence of resistance. In addition, oral manifestations can indicate as well as predict the progression of symptoms in patients with HIV/AIDS [1, 7-9]. At least one oral lesion is manifested in HIV/ AIDS patients [7-10]. These manifestations include hairy leukoplakia, oral candidiasis, Kaposi sarcoma, human papilloma virus and necrotizing ulcerative gingivitis [710]. The use of HAART can alter the prevalence of such manifestations $[7,9,10]$. In addition, there is an increased risk of developing dental caries in HIV patients who are not receiving HAART [9]. This demonstrates the important role of dentists in identifying new HIV/AIDS cases.

\section{Annual Symposia}

The centre has been holding annual symposia on recent advances in clinical virology for Kuwait and the EMRO region. International guest speakers and local faculty members present the most up-to-date information on recent advances in clinical virology (table 1).

\section{HIV Workshops}

In accordance with the requirements and guidelines of the centre's designation as a WHO collaboration centre, it has held annual training workshops on the application of molecular techniques in the diagnosis and management of HIV/AIDS for the EMRO region in collaboration with WHO EMRO every year since 2009. The expected outcome of these workshops is the training of local and other participants from the EMRO region nominated by WHO in the field of HIV/AIDS [1-3]. The centre's role and relationship to the WHO program is to develop national and international capacities in the field of molecular virology related to HIV/AIDS. Therefore, several workshops were held between 2005 and 2012 with regard to HIV (table 1).

\section{Summary}

The above describes recent activities of the WHO collaborating centre for AIDS for the EMRO region. As can be seen, the activities are varied and considerable, and the centre continues its activities based on a 4-year plan provided and approved by WHO $[1,3]$. For the centre to carry out these activities, it clearly has to have a strong staff with different areas of experiences, especially in the field of molecular virology and molecular biology. The introduction of powerful molecular techniques for HIV drug resistance detection, genotyping and viral load measurements was essential if the centre were to carry out its required obligations as a WHO collaborating centre for AIDS in the EMRO region. Despite these capabilities, of which WHO are aware, little has come in terms of requests for HIV investigations from WHO or the WHO EMRO or any country in the region. It is hoped that our 
Table 1. Dates and keynote speakers of 2005-2012 symposia and workshops

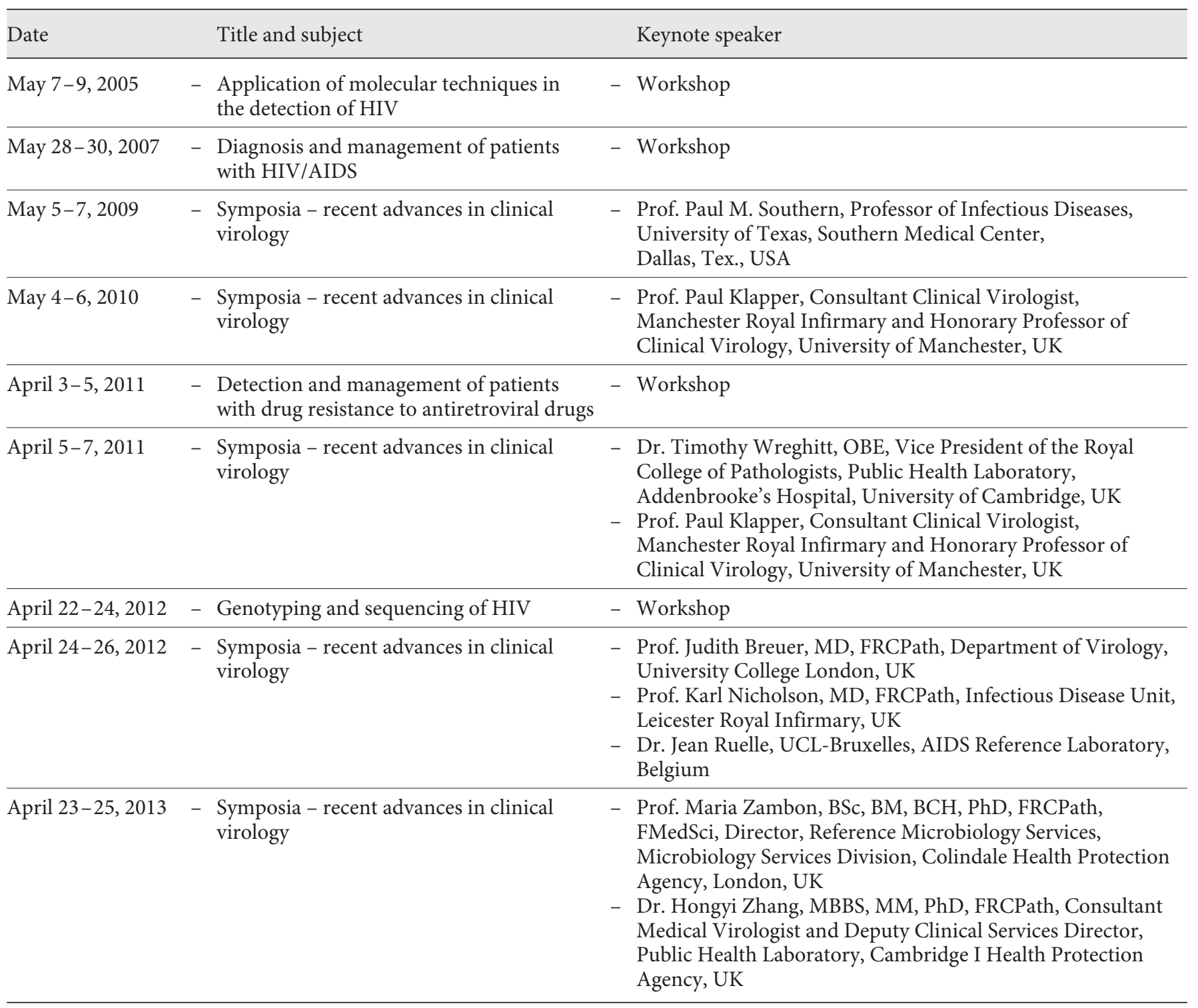

national project on HIV drug resistance will be extended to cover other countries in the region. This will stimulate collaboration between countries and will provide a better picture of the pattern of HIV drug resistance and prevalence of HIV genotypes circulating in this region. In contrast to investigations, the annual symposia and workshops were attended by staff from countries of the Gulf region, Sudan and Syria, in addition to staff from Kuwait. We feel that by designating the centre as a WHO collaborating centre for AIDS, it forced the centre to reach a high standard of work and practice that was in the interest of the centre itself and Kuwait. Indeed, the centre now serves
Kuwait as a reference centre for HIV and the director of the centre is a member of the National AIDS Committee and chairman of the National AIDS Subcommittee. Through these committees, work is coordinated to serve public health and issues relating to HIV/AIDS in the state of Kuwait [11] are addressed.

\section{Disclosure Statement}

The authors declare that no conflict of interest exists in relation to the content of the article. 


\section{References}

1 Guide for WHO collaborating centres. http:// www.who.int/collaboratingcentres/information/en/.

2 WHO collaborating centres: global database http://apps.who.int/whocc/Detail.aspx?cc ref=KUW-4\&cc_code=kuw\&.

3 Terms and conditions for WHO collaborating centres. http://www.who.int/collaboratingcentres/information/en/.

4 Siemens. http://www.medical.siemens.com/ siemens/en_GLOBAL/gg_diag_FBAs/files/ brochures/Molecular_Diagnostics/Trugene_ OsX_Spec_Sheet.pdf.
5 Roche. http://molecular.roche.com/instruments/Pages/COBASAmpliPrepInstrument. aspx.

6 Applied Biosystems. http://www.appliedbiosystems.com/absite/us/en/home.html.

7 Coogan MM, Greenspan J, Challacombe SJ: Oral lesions in infection with human immunodeficiency virus. Bull World Health Organ 2005;83:700-706.

-8 Fabian FM, Kahabuka FK, Peterson PE, et al: Oral manifestation among people living with HIV/AIDS in Tanzania. Int Dent J 2009;59: 187-191.
9 Nittayanata W, Talungchit S, Jaruratanasirikul S, et al: Effects of long-term use of HAART on oral health status of HIV infected subjects. J Oral Pathol Med 2010;39:397-406.

10 Freeman AD, Liberali SA, Coates EA, et al: Oral health in Australian HIV patients since the advent of combination of antiretroviral therapy. Aust Dent J 2012;57:470-476.

11 Ministerial decree No. 2253. Kuwait Ministry of Health, 2013. 